\title{
KESIAPSIAGAAN LEMBAGA PENDIDIKAN ANAK USIA DINI DALAM MENGHADAPI BENCANA BANJIR
}

\author{
Annisa Purwani ${ }^{1}$, Nurfadilah $^{1}$ \\ ${ }^{1}$ Program Studi Pendidikan Guru Pendidikan Anak Usia Dini, Fakultas Psikologi dan \\ Pendidikan, Universitas Al-Azhar Indonesia, Komplek Masjid Agung Al-Azhar Jl. \\ Sisingamangaraja, Jakarta Selatan, 12110 \\ E-mail : novanurfadilah@uai.ac.id
}

\begin{abstract}
ABSTRAK- Banjir merupakan salah satu kondisi yang membahayakan, terutama bagi Anak Usia Dini (AUD). Namun, terdapat beberapa lembaga Pendidikan Anak Usia Dini (PAUD) yang terletak di daerah rawan banjir. Hak anak untuk mendapatkan perlindungan tetap harus diusung meskipun lembaga PAUD berada di daerah rawan banjir. Dengan demikian lembaga PAUD perlu mengambil tindakan antisipasi, terutama pada saat musim hujan. Tujuan penelitian ini adalah untuk mendapatkan gambaran kesiapsiagaan lembaga PAUD dalam menghadapi bencana banjir. Metode yang digunakan adalah deskriptif kualitatif. Subjek penelitian dipilih menggunakan teknik purposive sampling, yaitu orang-orang yang terkait dengan kesiapsiagaan lembaga PAUD dalam menghadapi banjir. Kesiapsiagaan dikategorikan ke dalam 3 aspek yang sekaligus menjadi indikator penelitian, yaitu: (1) Aspek Struktural; (2) Aspek Non-Struktural; dan, (3) Aspek pengetahuan yang harus dimiliki oleh setiap guru dan siswa. Hasil penelitian menunjukkan bahwa kesiapsiagaan di lembaga PAUD dalam menghadapi bencana banjir terlihat beragam sesuai dengan kondisi dari masing-masing lingkungan sekolah. Pada lembaga PAUD B dan C hanya memprioritaskan 1 hal, yang secara berurutan adalah, memprioritaskan keamanan peralatan sekolah dan memprioritaskan keselamatan anak dan orang tua. Sedangkan Lembaga PAUD A memprioritaskan 2 hal, yaitu memprioritaskan keamanan peralatan sekolah serta persiapan peralatan yang akan digunakan di area pengungsian sementara. Hasil penelitian juga menunjukan bahwa ketiga lembaga PAUD masuk pada kategori kurang siap siaga berdasarkan penilaian pada setiap aspek kategrisasi kesiapsiagaan.
\end{abstract}

Kata Kunci: kesiapsiagaan, lembaga PAUD, Banjir

ABSTRACT - Flood is one of the dangerous conditions, especially for Early Childhood (AUD). However, there are several Early Childhood Education (PAUD) institutions located in flood-prone areas. The rights of children to obtain protection must still be carried out even though PAUD institutions are in flood-prone areas. Thus PAUD institutions need to take anticipatory actions, especially during the rainy season. The purpose of this study was to obtain an overview of PAUD institutions' preparedness in facing floods. The method used is descriptive qualitative. The research subjects were selected using a purposive sampling technique, namely people related to PAUD institution preparedness in the face of flooding. Preparedness is categorized into 3 aspects which are also indicators of research, namely: (1) Structural Aspects; (2) Non-Structural Aspects; and, (3) Knowledge aspects that must be possessed by every teacher and student. The results showed that preparedness in PAUD institutions in the face of flood disasters seemed to vary according to the conditions of each school environment. PAUD B and $C$ institutions only prioritize 1 thing, which in sequence is, prioritizing the safety of school equipment and prioritizing the safety of children and parents. While PAUD A prioritizes two things, namely prioritizing the safety of school equipment and preparing equipment to be used in the temporary evacuation area. The results of the study also showed that the three PAUD institutions were included in the category of under-preparedness based on the assessment of every aspect of preparedness categorization.

Keyword: Disaster Preparedness, ECDC, Flood 


\section{PENDAHULUAN}

\section{A. Latar Belakang}

$\mathrm{M}$ asa anak-anak adalah masa-masa dimana anak mengeksplorasi, mengembangkan minat, bakat, dan potensinya secara optimal. Masa eksplorasi anak perlu didukung dengan menciptakan lingkungan yang aman dan nyaman. Anak-anak perlu berada di lingkungan yang aman dan nyaman setiap saat untuk menjamin keselamatan mereka. Orangtua harus dapat menciptakan lingkungan yang aman dan nyaman ketika anak-anak berada di rumah, sedangkan guru harus dapat menciptakan lingkungan yang aman dan nyaman ketika anak-anak berada di sekolah.

Sekolah sebagai sebuah institusi pendidikan memiliki tanggung jawab yang besar terhadap masa depan anak-anak. Sekolah yang dicintai anak adalah sekolah yang dapat membuat anak merasa aman dan nyaman dalam kegiatan proses belajar mengajar. Sekolah harus dapat melindungi anak dari ancaman bahaya, kekerasan, bencana dan lainnya. Anak-anak perlu dilindungi dalam kondisi darurat karena anak-anak merupakan bagian dari kelompok rentan. Prioritas yang diberikan kepada kelompok rentan berupa penyelamatan, evakuasi, pengamanan, pelayanan kesehatan, dan psikososial oleh guru khususnya ketika anak-anak berada di sekolah agar anak merasa aman, nyaman, dan terlindungi dari ancaman.

Hal tersebut sudah menjadi tanggung jawab guru di sekolah, karena gurulah yang memiliki tanggung jawab dan tugas utama memberikan keamanan dan keselamatan bagi anak-anak di sekolah. Lingkungan sekolah merupakan hal dasar yang penting untuk diperhatikan oleh semua guru. Sebelum semua aktifitas pembelajaran dimulai guru harus menjamin bahwa lingkungan sekolah yang digunakan dalam keadaan aman untuk menjamin keselamatan anak (Maryana, 2010). Metode yang digunakan oleh guru untuk mengingatkan anak dalam kondisi aman dan tidak aman adalah dengan metode daftar cek keselamatan (Maryana, 2010). Metode ini membantu guru mengatur dan memastikan kondisi kelas di lingkungan sekolah dalam kondisi aman. Salah satu kondisi aman yang perlu diciptakan sekolah adalah dalam hal bencana banjir. Kesiapsiagaan bencana banjir merupakan elemen penting yang harus dipersiapkan oleh guru. Oleh karena itu pihak sekolah harus membuat perencanaan untuk menjamin pemenuhan hak-hak anak dan untuk keselamatan seluruh pihak yang berada di lembaga PAUD.

\section{B. Fokus dan Sub fokus Masalah}

Berdasarkan latar belakang di atas dapat ditarik fokus dan subfokus permasalahan sebagai berikut:

1. Fokus Masalah

Kesiapsiagaan Lembaga Pendidikan Anak Usia Dini dalam menghadapi bencana banjir.

2. Sub Fokus Masalah, meliputi :

a. Bagaimana kesiapsiagaan lembaga pendidikan anak usia dini dalam menghadapi bencana banjir?

b. Bagaimana kategorisasi kesiapsiagaan lembaga pendidikan anak usia dini dalam menghadapi bencana banjir sesuai dengan daerah lingkungannya?

\section{Tujuan Penelitian}

Adapun tujuan dari penelitian ini adalah sebagai berikut:

1. Untuk mendeskripsikan kesiapsiagaan Lembaga Pendidikan Anak Usia Dini dalam menghadapi bencana banjir.

2. Untuk mengkategorisasi kesiapsiagaan Lembaga Pendidikan Anak Usia Dini dalam menghadapi bencana banjir sesuai dengan daerah lingkungannya.

\section{Manfaat Penelitian}

Manfaat praktis yang diharapkan dari penelitian ini adalah:

1. Bagi guru

Hasil penelitian ini diharapkan dapat memberikan pengetahuan tentang kesiapsiagaan, idealnya Lembaga PAUD melalui serangkaian kegiatan untuk merencanakan kesiapsiagaan banjir di Lembaga PAUD.

2. Orangtua

Hasil penelitian ini diharapkan dapat memberikan pengetahuan kepada orangtua agar ikut terlibat dalam kesiapsiagaan yang dilakukan oleh Lembaga PAUD bekerjasama memberikan informasi, membantu memulihkan keadaan dll. 
3. Masyarakat

Hasil penelitian ini diharapkan dapat memberikan pengetahuan kepada masyarakat tentang pentingnya keterlibatan masyarakat dalam menangani dan membantu Lembaga PAUD dalam kesiapsiagaan yang berada di lingkungannya.

4. Peneliti selanjutnya

Hasil penelitian ini diharapkan dapat dijadikan sebagai bahan referensi untuk melakukan penelitian lebih lanjut apa saja yang bisa dieksplorasi lebih jauh terkait dengan kesiapsiagaan menghadapi bencana banjir di Lembaga PAUD.

\section{KAJIAN TEORI}

\section{A. Perlindungan Anak}

Anak-anak berhak mendapatkan perlindungan dalam situasi dan kondisi tertentu (kondisi darurat). Pentingnya mendapatkan jaminan rasa aman terhadap ancaman yang membahayakan diri dan jiwa pada tumbuh kembang anak sesuai dengan Undang-Undang Nomor 23 Tahun 2002 tentang perlindungan anak pasal (1) yang menyebutkan bahwa segala kegiatan untuk menjamin dan melindungi anak dan hakhaknya agar dapat hidup, tumbuh, berkembang, dan berpartisipasi secara optimal sesuai dengan harkat dan martabat kemanusiaan, serta mendapat perlindungan dari kekerasan dan diskriminasi. Perlindungan khusus adalah suatu bentuk perlindungan yang diterima oleh Anak dalam situasi dan kondisi tertentu (darurat) untuk mendapatkan jaminan rasa aman terhadap ancaman yang membahayakan diri dan jiwa dalam tumbuh kembangnya.

Anak-anak harus dilindungi dalam kondisi darurat, karena anak-anak merupakan bagian dari kelompok rentan. Kelompok rentan diberikan prioritas berupa penyelamatan, evakuasi, pengamanan, pelayanan kesehatan, dan psikososial oleh guru khususnya ketika anak-anak di sekolah agar anak merasa aman, nyaman, dan terlindungi dari ancaman sebagaimana dimandatkan dalam UndangUndang Nomor 24 Tahun 2007 tentang penanggulangan bencana (dalam Astuti, dkk., 2013) Perlindungan terhadap kelompok rentan sebagaimana dimandatkan dalam Pasal 48 ayat 1 dilakukan dengan memberikan prioritas kepada kelompok rentan berupa penyelamatan, evakuasi, pengamanan, pelayanan kesehatan, dan psikososial. Kelompok rentan pada ayat 2 sebagaimana dimaksud pada ayat 1 terdiri atas: (a) Bayi, balita, dan anak-anak; (b) Ibu yang sedang mengandung atau menyusui; (c) Penyandang cacat; dan (d) Orang lanjut usia.

\section{B. Kesiapsiagaan Bencana Banjir}

Kesiapsiagaan adalah tindakan penyusunan rencana penanggulangan bencana, pemeliharaan sumberdaya dan pelatihan personil (Ariantoni, 2009) sedangkan kesiapsiagaan menurut UNESCO (2007) yaitu kegiatan yang memungkinkan sekolah untuk dapat bertindak dengan cepat dan efektif ketika terjadi bencana banjir. Berdasarkan beberapa definisi kesiapsiagaan tersebut dapat disimpulkan bahwa kesiapsiagaan adalah tindakan dalam perencanaan menghadapi bencana yang dilakukan dengan cepat dan efektif ketika menghadapi bencana banjir. Hal ini membantu dalam membentuk dan merencanakan tindakan apa saja yang perlu dilakukan ketika banjir, kesuksesan dalam penanganan dan evakuasi ketika banjir sangat bergantung dari kesiapsiagaannya dalam menghadapi banjir. Kesiapsiagaan dalam perencanaan penanggulangan banjir terdiri dari : kesiapsiagaan sebelum banjir, ketika banjir, dan setelah banjir (Ariantoni, 2009).

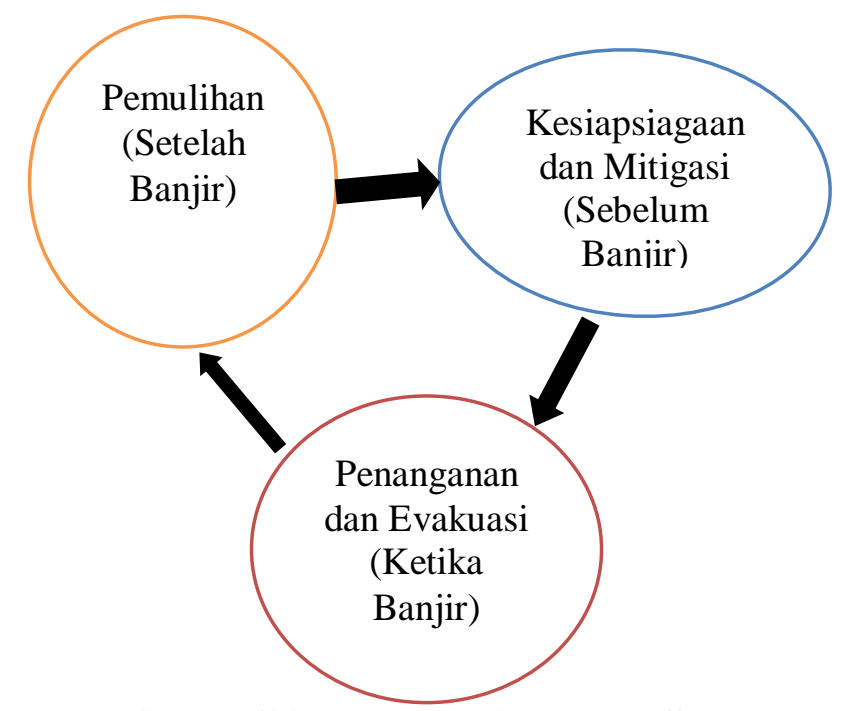

Gambar 1. Siklus Penanggulangan Banjir

Tahapan-tahapan penanggulangan banjir sesuai dengan gambar di atas terdiri dari: (1) Kesiapsiagaan sebelum banjir; (2) Ketika banjir; dan (3) Setelah banjir. Kegiatan tersebut di dalamnya berhubungan satu sama 
lain dan harus dilaksanakan secara bertahap dan terus menerus. Kegiatan kesiapsiagaan tersebut menurut UNESCO (2007) meliputi: (1) Persiapan pembentukan sistem peringatan, sosialisasi evakuasi, dan lokasi tempat evakuasi sebelum musim hujan; (2) Pencarian dan penyelamatan korban pada saat banjir; (3) Rehabilitasi dan rekonstruksi setelah banjir. Kesiapsiagaan dilakukan dalam rangka upaya mengelola risiko bencana, sehingga jika telah siaga dampak dari bencana dapat diminimalisir.

\section{Kesiapsiagaan Sekolah dalam Menghadapi Bencana Banjir}

Kesiapsiagaan merupakan salah satu upaya mengurangi resiko dan mengantisipasi bencana. Sekolah sebagai sebuah institusi pendidikan memiliki tanggung jawab yang besar terhadap masa depan peserta didiknya. Sekolah merupakan sebuah tempat menyediakan ruang yang aman dan nyaman untuk mengembangkan diri dan anak-anak merupakan bagian dari masyarakat luas yang juga memiliki peran penting dalam kehidupan masyarakat (Ariantoni, dkk., 2009).

Sekolah yang aman berdasarkan Peraturan Kepala Badan Nasional Penanggulangan Bencana Nomor 4 Tahun 2012 tentang pedoman penerapan sekolah aman dari bencana adalah sekolah yang menerapkan standar sarana dan prasarana yang mampu melindungi warga sekolah dan lingkungan di sekitarnya dari bahaya bencana. Penerapan sekolah aman dari bencana terutama didasarkan pada pertimbangan sebagai berikut: (1) Mengurangi gangguan terhadap kegiatan pendidikan, sehingga memberikan jaminan kesehatan, keselamatan, kelayakan termasuk bagi anak berkebutuhan khusus, kenyamanan, dan keamanan di sekolah setiap saat; (2) Sekolah sebagai tempat belajar yang lebih aman memungkinkan identifikasi dan dukungan terhadap bantuan kemanusiaan lainnya untuk anak dalam situasi darurat sampai pemulihan pasca bencana; (3) Sekolah dapat dijadikan pusat kegiatan masyarakat dan merupakan sarana sosial yang sangat penting dalam memerangi kemiskinan, buta huruf dan gangguan kesehatan; (4) Sekolah menjadi pusat kegiatan masyarakat dalam mengkoordinasi pemulihan setelah terjadi bencana; (5) Sekolah dapat menjadi rumah darurat untuk melindungi bukan saja populasi sekolah tetapi juga komunitas dimana sekolah itu berbeda.

Berdasarkan uraian di atas diketahui bahwa sekolah mempunyai peranan penting dalam menciptakan kondisi aman dan nyaman bagi anak-anak ketika berada di sekolah. Adapun indikator sekolah aman yang tercantum dalam Peraturan BNPB No.4 Tahun 2012 tentang Pedoman Penerapan Sekolah Aman dari Bencana mengacu pada 2 aspek yaitu struktural dan non-struktural (dalam Parino, 2013).

Tabel 1. merupakan indikator sekolah aman pada aspek struktural yang terdiri dari struktur bangunan, arsitektural, dan tata ruang.

Tabel 1. Indikator Sekolah Aman (Struktural)

\begin{tabular}{|c|c|}
\hline Aspek & Indikator \\
\hline \multirow{3}{*}{$\begin{array}{l}\text { Struktur } \\
\text { Bangunan }\end{array}$} & $\begin{array}{ll}\text { 1. } & \text { Menggunakan komponen struktur } \\
\text { sloof, balok dan kolom }\end{array}$ \\
\hline & \begin{tabular}{|l} 
2. Dimensi besi sesuai dengan standar \\
Permen PU/45/PRT/2007 tentang \\
pedoman Teknis Bangunan Gedung \\
Negara \\
\end{tabular} \\
\hline & $\begin{array}{ll}\text { 3. } & \text { Terdapat ikatan antar komponen } \\
\text { sesuai dengan ketentuan teknis PU }\end{array}$ \\
\hline \multirow{9}{*}{ Arsitektural } & $\begin{array}{l}\text { 4. Bahan dinding, lantai, atap, kusen, } \\
\text { plafon sesuai dengan standar SNI }\end{array}$ \\
\hline & 5. Lantai tidak licin dan berlubang \\
\hline & 6. $\quad$ Pintu 2 daun dan terbuka lebar \\
\hline & $\begin{array}{l}\text { 7. Tersedia air bersih untuk minum } \\
\text { dan sanitasi, energi listrik dan/ atau } \\
\text { gas yang cukup serta memenuhi } \\
\text { standar aman }\end{array}$ \\
\hline & $\begin{array}{ll}\text { 8. } & \text { Tersedia air yang cukup untuk } \\
\text { pemadaman kebakaran }\end{array}$ \\
\hline & 9. Tersedia alat pemadam kebakaran \\
\hline & $\begin{array}{l}\text { 10. Tiang bendera, emari dan papan } \\
\text { nama diangkurkan }\end{array}$ \\
\hline & $\begin{array}{l}\text { 11. Bahan berbahaya dan beracun } \\
\text { disimpan di tempat aman dan } \\
\text { diangkurkan }\end{array}$ \\
\hline & $\begin{array}{l}\text { 12. Meja kokoh dan cukup untuk } \\
\text { tempat belindung }\end{array}$ \\
\hline \multirow{5}{*}{ Tata Ruang } & 13. Terdapat garis sempadan \\
\hline & 14. Simetris \\
\hline & 15. Terdapat area untuk evakuasi \\
\hline & 16. Koridor cukup luas untuk evakuasi \\
\hline & $\begin{array}{lll}\text { 17. Tata ruang kelas tidak } \\
\text { mengahalangi evakuasi }\end{array}$ \\
\hline
\end{tabular}

Sumber : BNPB No. 4 Tahun 2012

Berkaitan dengan hal tersebut maka sekolah perlu melakukan proses perencanaan, pengadaan dan perawatan fasilitas sekolah untuk mempertimbangkan kerentanan dan kerawanan terhadap bencana. Sekolah 
diharapkan akan menjadi wahana bagi masyarakat bagaimana merancang, melaksanakan, dan mengevakuasi ketika terjadi bencana. Tabel 2. merupakan tabel indikator sekolah aman pada aspek nonstruktural yang terdiri dari kapasitas, perencanaan, kebijakan, mobilisasi sumber daya.

Tabel 2. Indikator Sekolah Aman (NonStruktural)

\begin{tabular}{|c|c|}
\hline Aspek & Indikator \\
\hline \multirow[t]{2}{*}{ Kapasitas } & $\begin{array}{l}\text { 1. Mengenali jenis-jenis bencana } \\
\text { potensial di lingkungan sekolah }\end{array}$ \\
\hline & $\begin{array}{l}\text { 2. Pengetahuan, sikap dan } \\
\text { keterampilan terhadap bencana }\end{array}$ \\
\hline \multirow[t]{6}{*}{ Perencanaan } & $\begin{array}{l}\text { 3. Memiliki peta-peta hasil } \\
\text { penilaian kondisi sekolah } \\
\text { (struktural-non struktural) }\end{array}$ \\
\hline & $\begin{array}{l}\text { 4. Mempunyai recana induk } \\
\text { sekolah aman }\end{array}$ \\
\hline & $\begin{array}{ll}\text { 5. } & \text { Mempunyai rencana } \\
\text { pengembangan jangka } \\
\text { menengah sekolah (RP JMSA) } \\
\text { sekolah aman }\end{array}$ \\
\hline & $\begin{array}{l}\text { 6. Mempunyai DED rehabilitasi } \\
\text { bangunan sekolah yang tahan } \\
\text { gempa }\end{array}$ \\
\hline & $\begin{array}{l}\text { 7. Mempunya RAB rehabilitasi } \\
\text { sekolah aman }\end{array}$ \\
\hline & $\begin{array}{l}\text { 8. Mempunyai rencana aksi } \\
\text { tahunan }\end{array}$ \\
\hline \multirow[t]{4}{*}{ Kebijakan } & $\begin{array}{l}\text { 9. Kebijakan yang dikembangkan } \\
\text { menjamin keamanan sekolah }\end{array}$ \\
\hline & $\begin{array}{l}\text { 10. Memiliki prosedur operasional } \\
\text { dan pemeliharaan bangunan }\end{array}$ \\
\hline & $\begin{array}{l}\text { 11. Memiliki prosedur tetap } \\
\text { evakuasi dan peringatan dini }\end{array}$ \\
\hline & $\begin{array}{l}\text { 12. Terdapat poster jalur evakuasi } \\
\text { yang dipasang di tempat } \\
\text { strategis }\end{array}$ \\
\hline \multirow{4}{*}{$\begin{array}{l}\text { Mobilisasi } \\
\text { Sumber Daya }\end{array}$} & $\begin{array}{l}\text { 13. Memiliki Komite Bencana dan } \\
\text { Keselamatan Sekolah }\end{array}$ \\
\hline & $\begin{array}{l}\text { 14. Melakukan kegiatan simulasi } \\
\text { evakuasi secara rutin }\end{array}$ \\
\hline & $\begin{array}{l}\text { 15. Memiliki cadangan makanan } \\
\text { dan minuman untuk kondisi } \\
\text { darurat }\end{array}$ \\
\hline & $\begin{array}{l}\text { 16. Memiliki sarana dan prasarana } \\
\text { untuk tanggap darurat seperti } \\
\text { tendu dan P3K }\end{array}$ \\
\hline
\end{tabular}

Penerapan sekolah aman dari bencana dapat mengurangi hambatan kegiatan pendidikan, sehingga memberi jaminan kesehatan, keselamatan, kenyamanan, dan keamanan yang mampu melindungi warga sekolah dan lingkungan sekolah sekitarnya dari bahaya bencana di sekolah setiap saat. Dengan demikian anak-anak merupakan bagian dari kelompok rentan mendapatkan perlindungan ketika kondisi darurat.

Idealnya setiap lembaga PAUD melalui serangkaian proses sebagai berikut: (1) mengikuti pelatihan atau pembekalan tentang penanggulangan bencana dan pengurangan risiko bencana; (2) Melakukan kajian risiko di sekitar lokasi lembaga PAUD; Merencanakan integrasi kurikulum ke dalam rencana belajar tahunan, bulanan, mingguan dan harian serta pemantauan hasil belajar; (4) Memadukan pendidikan kesiagaan bencana ke dalam kebijakan sekolah (Aditya dan Andina, 2011). Tujuannya yaitu: (1) Memberikan bekal pengetahuan kepada peserta didik (2) Memberikan keterampilan agar peserta didik mampu berperan aktif dalam pengurangan risiko bencana baik pada diri sendiri dan lingkungannya; (3) Memberikan tentang potensi bencana dan risiko yang mungkin ditimbulkan; (4) Memberikan pengetahuan dan wawasan tentang bencana di Indonesia kepada siswa sejak dini; (5) Memberikan pemahaman kepada pendidik tentang bencana, penyelamatan diri bila terjadi bencana; (6) Memberikan keterampilan kepada pendidik dalam menyusun perencanaan, melaksanakan dan melakukan simulasi kesiapsiagaan kepada siswa; (7) Memberikan wawasan, pengetahuan dan pemahaman bagi pihak terkait sehingga diharapkan dapat memberikan dukungan terhadap kelancaran pelaksanaan pembelajaran tentang bencana.

\section{METODE PENELITIAN}

\section{A. Pendekatan Penelitian}

Penelitian ini menggunakan pendekatan deskriptif kualitatif. Menurut Moleong (2005), pendekatan deskriptif kualitatif merupakan prosedur penelitian yang menghasilkan data deskriptif. Laporan penelitian yang menggunakan pendekatan deskriptif kualitatif berisi kutipan-kutipan data untuk memberi gambaran penyajian laporan tersebut.

Jenis pendekatan penelitian ini bertujuan memberikan gambaran secara terperinci mengenai suatu tindakan yang dilakukan akibat gejala bencana yaitu untuk mendapatkan suatu gambaran kesiapsiagaan sekolah dalam menghadapi bencana banjir di Lembaga Pendidikan Anak Usia Dini.

\section{B. Tempat dan Waktu Penelitian}

Penelitian dilakukan di tiga Lembaga PAUD daerah Jakarta Selatan. Lembaga PAUD A dan B berada di Jl. Kebon Baru Tebet lokasinya dekat dengan bantaran sungai Ciliwung sehingga rawan banjir. Lembaga 
PAUD ke tiga terletak di daerah Bangka Mampang Prapatan yang akses jalannya sering mengalami banjir. Sebelum penelitian dilakukan, peneliti melakukan observasi awal, Lembaga PAUD pertama diketahui bahwa tetap melakukan pembelajaran ketika Lembaganya banjir, Lembaga PAUD ke dua menghentikan pembelajaran pada saat Lembaganya banjir, dan Lembaga PAUD ke tiga tetap melakukan pembelajaran walaupun akses jalan Lembaganya terkena banjir.

\section{Teknik Pengambilan Sampel}

Teknik yang dipilih peneliti adalah purposive sampling. Purposive sampling menurut Sugiyono (2005) adalah teknik pemilihan informan sebagai sumber data dengan pertimbangan tertentu. Pertimbangan penulis misalnya orang tersebut yang dianggap paling tahu tentang apa yang diharapkan, atau mungkin sebagai penguasa sehingga akan memudahkan penulis menjelajahi objek atau situasi sosial yang di teliti.

Subjek penelitian adalah orang-orang yang terkait dalam kesiapsiagaan sekolah dalam menghadapi bencana banjir. Subjek penelitian pada TK A ialah pengelola yang berjumlah 2 (dua) orang, terdiri atas ketua yayasan, serta kepala sekolah yang merangkap sebagai pendidik dan tenaga administrasi. Kedua informan tersebut dianggap sebagai orang yang dapat memberikan sumber informasi secara akurat. Subjek penelitian TK B adalah pengelola yang berjumlah 2 (dua) orang, terdiri atas 1 orang Kepala Sekolah yang merangkap sebagai pendidik, dan 1 orang pendidik. Subjek penelitian TK $\mathrm{C}$ adalah pengelola yang berjumlah 2 (dua) orang terdiri atas 1 orang Kepala Sekolah, dan 1 orang pendidik.

\section{Sumber data}

Sumber data penelitian disesuaikan dengan tujuan dilakukannya penelitian. Sumber data yang dimaksud menurut Arikunto (2002) adalah "subyek dari mana data diperoleh". Sumber data dalam penelitian ini terdiri dari :

\section{Data primer}

Data primer menurut Sugiyono (2005) adalah "sumber data yang langsung memberikan data kepada pengumpul data". Data primer yang didapatkan melalui wawancara secara langsung dari subyek dan orang-orang yang menjadi informan yang mengetahui pokok permasalahan atau obyek penelitian tentang kesiapsiagaan Lembaga PAUD menghadapi banjir di TK Nurul Hafi yang melakukan proses pembelajaran pada saat keadaan darurat, TK Flamboyan yang berada dekat dengan daerah TK Nurul Khafi tetapi tidak melakukan proses pembelajaran atau sekolah diliburkan, dan TK Kembang yang mengalami hambatan banjir pada akses jalan menuju sekolah.

2. Data sekunder

Data Sekunder adalah sumber data yang tidak langsung diperoleh pengumpul data, misalnya alat perekam dan dokumen. Alat perekam digunakan untuk mendapatkan informasi dalam mengumpulkan data. Dokumen yang didapatkan berupa RKH (Rencana Kegiatan Harian), RKM (Rencana Kegiatan Mingguan), dan kebijakan sekolah tentang peraturan tata tertib, serta didukung oleh foto-foto kegiatan penelitian di TK Nurul Hafi, TK Flamboyan, dan TK Kembang.

\section{E. Teknik dan Prosedur Pengumpulan Data}

Teknik pengumpulan data yang dilakukan meliputi: wawancara, observasi, dan dokumentasi.

1. Wawancara

Wawancara menurut Mukhtar (2013) adalah "proses tanya jawab antara peneliti dengan subjek penelitian atau informan dalam situasi sosial". Jenis wawancara yang digunakan ialah wawancara mendalam (Indepth Interview) dan wawancara terbuka. Wawancara mendalam/Indepth Interview adalah proses memperoleh keterangan untuk tujuan penelitian dengan cara tanya jawab sambil bertatap muka antara pewawancara dan informan atau orang yang diwawancarai, dengan atau tanpa menggunakan pedoman (guide) wawancara, yaitu pewawancara dan informan terlibat dalam kehidupan sosial yang relatif lama (Prastowo, 2010). Selanjutnya, wawancara terbuka yaitu subjek mengetahui bahwa dirinya sedang diwawancarai dan memahami maksud dan 
tujuan dari wawancara yang dilakukan oleh peneliti (Moleong, 2013).

Adapun jenis instrumen yang dipilih ialah instrumen tertutup, berupa seperangkat daftar pertanyaan yang dijawab langsung oleh subjek penelitian, tanpa disediakan jawaban oleh peneliti (Mukhtar, 2013). Instrumen tersebut dijadikan pedoman wawancara mengenai kesiapsiagaan Lembaga PAUD dalam menghadapi bencana banjir di Jakarta Selatan.

Alasan digunakan wawancara terbuka adalah penulis terlibat langsung mewawancarai informan yang dipilih sebagai orang yang mengetahui tentang perihal yang terjadi dalam kehidupan sosial dan informan menyadari bahwa dirinya sedang diwawancarai serta mengetahui maksud dan tujuan dari wawancara yang dilakukan oleh penulis. Kemudian alasan instrumen tertutup yang dipilih sebagai jenis instrumen karena penulis sudah membuat seperangkat daftar pertanyaan tetapi penulis tidak memberikan pilihan jawaban ketika melakukan wawancara, penulis memberikan kebebasan kepada informan untuk menjawab pertanyaan yang diajukan oleh penulis.

a. Pemilihan Subjek

Penelitian diawali dengan kunjungan ke TK untuk menanyakan kesediaan Lembaga PAUD yang mengalami kendala bencana banjir dalam penelitian ini, kemudian penulis menentukan jumlah informan mengenai hal yang terkait dengan kesiapsiagaan sekolah dalam menghadapi bencana (banjir) di TK A.Terdapat 4 subjek penelitian dikarena Ketua Yayasan dengan Kepala Sekolah berperan menjadi guru dan pernah mengalami bencana banjir. Mereka datang ke sekolah dan menangani langsung sedangkan semua guru yang pernah mengalami kejadian tersebut sudah tidak mengajar di sekolah tersebut. Guru yang mengajar saat ini merupakan guru baru dan belum berpengalaman dalam menangani kejadian tersebut. Wawancara di TK A juga dilakukan terhadap 1 orangtua murid kemudian 1 orang tokoh masyarakat sekitar lingkungan daerah TK A yang mengalami banjir yang sama dengan pihak pengelola.

Terdapat 4 subyek penelitian di TK B, yaitu kepala sekolah dan 1 orang guru sebagai orang yang pernah mengalami kejadian tersebut. Selain itu, satu orang orangtuadan satu orang tokoh masyarakat yang pernah mengalami kejadian tersebut juga diwawancarai.

Pada TK C terdapat 4 orang subjek penelitian, yaitusatu orang kepala sekolah, satu orang guru, dan dua orang orangtua yang pernah mengalami kejadian tersebut.

b. Penyusunan instrumen

Subjek penelitian diberikan pertanyaan yang sudah disusun dalam pedoman wawancara. Pedoman ini disusun berdasarkan teori yang berkaitan dengan masalah yang diteliti agar tujuan penelitian tercapai.

c. Wawancara

Wawancara dilakukan sendiri oleh peneliti dan untuk memudahkan peneliti menggunakan kode-kode untung para informan. Berikut penjelasannya: Informan I (TK A) daerah Tebet (CW-01 [Catatan Wawancara Sekolah 1]).

Tabel 3. Kode Informan I

\begin{tabular}{|c|c|}
\hline Informan & Kode \\
\hline Ketua Yayasan & CWG1-01 \\
\hline $\begin{array}{c}\text { Kepala Sekolah } \\
\text { dan Guru }\end{array}$ & CWG2-01 \\
\hline Masyarakat 1 & CWMSY-01 \\
\hline Orangtua 1 & CWOT-01 \\
\hline
\end{tabular}

Informan II (TK B) daerah Tebet (CW-02 [Catatan Wawancara Sekolah 2]). 
Tabel 4. Kode Informan II

\begin{tabular}{|c|c|}
\hline Informan & Kode \\
\hline Kepala Sekolah & CWG1-02 \\
\hline Guru 1 & CWG2-02 \\
\hline Orangtua 1 & CWOT-02 \\
\hline Masyarakat 1 & CWMSY-02 \\
\hline
\end{tabular}

Informan III (TK C) daerah Kemang (CWS3 [Catatan Wawancara Sekolah $3])$.

Tabel 5. Data Informan III

\begin{tabular}{|c|c|}
\hline Informan & Kode \\
\hline Kepala Sekolah & CWG1-03 \\
\hline Guru 1 & CWG2-03 \\
\hline Orangtua 1 & CWOT1-03 \\
\hline Orangtua 2 & CWOT2-03 \\
\hline
\end{tabular}

\section{Observasi}

Menurut Moleong (2002) observasi adalah pengumpulan data yang dilakukan dengan cara mengamati dan mencatat secara sistematis gejala-gejala yang diteliti. Pengamatan yang dilakukan adalah pengamatan terbuka yaitu pengamatan yang diketahui oleh subyek, sehingga subyek dengan sukarela memberikan kesempatan kepada pengamat untuk mengamati peristiwa yang terjadi dan mereka menyadari ada orang lain yang mengamati (Moleong, 2002).

Hal yang diobservasi ialah hal-hal yang terkait dengan indikator sekolah aman (Struktural) di Lembaga PAUD dengan menggunakan pedoman observasi. Hasil pengamatan yang dilakukan langsung dituangkan ke dalam catatan observasi berupa ceklis yang berisi (terlihat dan tidak terlihat) pada satu lembar observasi yang telah dibuat.

3. Dokumentasi

Menurut Guba dan Lincon (dalam Moleong, 2002) dokumentasi adalah setiap bahan tertulis ataupun film yang dipersiapkan karena adanya permintaan seorang penyidik. Dokumentasi adalah suatu metode pengumpulan data yang dilakukan dengan cara mengadakan pencatatan atau pengutipan data dari dokumen yang ada di lokasi penelitian.

Alasan digunakannya metode dokumentasi yaitu untuk memperkuat data-data yang sudah ada seperti hasil data dari observasi dan wawancara. Alat dokumentasi yang digunakan adalah alat perekam seperti camera dan HP. Adapun data dari hasil dokumentasi yang didapat oleh peneliti dapat berupa arsip-arsip yang meliputi data tentang penunjang kesiapsiagaan sekolah dalam menghadapi bencana banjir seperti kebijakan sekolah tentang peraturan tata tertib sekolah, rencana kegiatan harian, rencana kegiatan mingguan serta foto-foto kegiatan penulis pada saat wawancara.

\section{Alat Perekam}

Selain dokumentasi, juga digunakan alat perekam untuk mengumpulkan data pada saat wawancara. Alat perekam tersebut digunakan setelah mendapat izin dari subjek untuk mempergunakan alat tersebut pada saat wawancara berlangsung. Selain alat perekam, juga digunakan kamera foto untuk mengabadikan keadaan saat melakukan penelitian.

\section{F. Analisis Data}

Menurut Bogdan Biklen (dalam Moleong, 2005) analisis data kualitatif adalah upaya yang dilakukan dengan jalan bekerja dengan data, mengorganisasian data, memilahmiihnya menjadi satuan yang dapat dikelola, mensistensikannya, mencari dan menemukan pola, menentukan apa yang penting dan apa yang dipelajari, dan memutuskan apa yang diceritakan kepada orang lain.

Analisis data yang digunakan ialah pendekatan penelitian kualitatif. Data yang diperoleh dari hasil wawancara, observasi dan dokumentasi harus segera dianalisis setelah dikumpulkan dan dituangkan dalam bentuk laporan lapangan. Hasil dari laporan lapangan kemudian direduksi, yaitu memilih hal-hal pokok yang sesuai dengan fokus penelitian. Data yang didapat di lapangan langsung diketik dan ditulis dengan rapi, terperinci serta sistematis setiap selesai mengumpulkan data.

Mereduksi data berarti merangkum, memilih hal-hal yang pokok, memfokuskan 
pada hal-hal yang penting, dicari tema dan polanya. Dengan demikian data yang telah direduksi akan memberikan gambaran yang lebih jelas, dan mempermudah penulis untuk melakukan pengumpulan data selanjutnya, serta mencarinya bila diperlukan (Sugiyono, 2005).

\section{G. Keabsahan Data}

Keabsahan data dilakukan menggunakan teknik triangulasi. Teknik triangulasi adalah teknik pemeriksaan keabsahan data yang memanfaatkan sesuatu yang lain di luar data untuk keperluan pengecekan atau sebagai pembanding terhadap data itu (Moleong, 2006). Denzin (dalam Moleong, 2006) membedakan 4 triangulasi, yaitu :

1. Triangulasi Sumber

Berarti membandingkan dan mengecek balik derajat kepercayaan suatu informasi yang diperoleh melalui waktu dan alat yang berbeda dalam penelitian kualitatif. Hal ini dapat dicapai dengan jalan sebagai berikut : membandingkan data hasil wawancara, membandingkan apa yang dikatakan orang didepan umum dengan apa yang dikatakannya secara pribadi, membandingkan apa yang dikatakan orang-orang tentang situasi penelitian dengan apa yang dikatakan sepanjang waktu, membandingkan keadaan dan perspektif seseorang dengan berbagaii pendapat dan pandangan orang, seperti rakyat biasa, orang yang berpendidikan menengah atau tinggi, orang berada atau pemerintahan, dan membandingkan hasil wawancara dengan isi suatu dokumen yang berkaitan.

2. Triangulasi Metode

Menurut Patton dan Moleong (2006) terdapat 2 (dua) strategi, yaitu: pengecekan derajat kepercayaan penemuan hasil penelitian dengan beberapa teknik pengumpulan data dan pengecekan derajat kepercayaan beberapa sumber data dengan metode yang sama.

3. Triangulasi Teknik

Triangulasi teknik yaitu dengan jalan memanfaatkan penulis untuk keperluan pengecekan kembali derajat kepercayaan data. Pemanfaatan pengamatan lainnya ialah dapat membantu mengurangi kemelencengan-kemelencengan data.

4. Triangulasi Teori

Triangulasi Teori yaitu membandingkan teori yang ditemukan berdasarkan kajian lapangan dengan teoriteori yang telah diuraikan dalam bab kajian teori yang telah ditemukan. Adapun jenis triangulasi yang dipilih ialah triangulasi sumber. Teknik triangulasi sumber ialah menghimpun data dari hasil wawancara, observasi, dan dokumentasi. Selanjutya dilakukan pengecekan terhadap kesesuaian dari ketiganya, yaitu kesesuaian data antara hasil wawancara dengan keadaan yang terjadi di lapangan (hasil dari pengamatan/observasi) serta data yang didapat dari studi dokumentasi.

\section{HASIL DAN PEMBAHASAN}

\section{A. Hasil Penelitian}

1. Temuan Umum

a. Deskripsi Lokasi Penelitian

Lokasi penelitian terdapat di 2 tempat yang berbeda, lokasi subjek pertama dan kedua di Jl. H Gg. Y Kebonbaru Tebet Jakarta Selatan (CWG1-01). Akses menuju lokasi dari stasiun Universitas Indonesia bisa ditempuh dengan naik kereta Commuterline turun di stasiun Cawang kemudian dilanjutkan dengan angkutan umum jurusan kampung Melayu atau bisa menggunakan ojek (CD1-01; CD1-02). Lokasi subjek kedua berada di Jl.Kemang Raya No. 2 Kelurahan Bangka Mampang Prapatan Jakarta Selatan. Tepatnya di belakang McDonald's Kemang sebelum lampu merah, di seberang Swiss Belhotel (CWG1-02) (CD1-03).

b. Lingkungan Fisik Penelitian dan Sejarah Berdirinya Sekolah

Adapun kondisi fisik tempat penelitian ini adalah sebagai berikut. Lembaga PAUD A berada di lingkungan rumah penduduk. Lembaga PAUD (01) tersebut menyatu dengan rumah pemiliknya, ada beberapa kamar yang dipakai untuk kelas dan ruang tengah juga 
dipakai ruang kelas. Halaman rumah dipakai ruang bermain, sedangkan ruang tamu dijadikan ruang kantor. Jalan depan sangat sempit hanya bisa dilalui oleh satu motor dan tidak bisa dilewati oleh mobil, didepannya terdapat aliran selokan air yang mengalir (CD2-03).

Sejarah berdirinya Lembaga PAUD A (01) awalnya hanya pengajian anak-anak saja. Seiring berjalannya waktu kemudian membuat seragam anak-anak, anak-anak mendapatkan seragam dengan bebas biaya. Kebutuhan anak-anak untuk mendapat pendidikan formal akhirnya di buat sekolah TK tujuannya adalah untuk masyarakat yang ekonomi lemah. Orientasi membantu masyarakat lemah agar bisa mendapat pendidikan formal (CWG1-01).

Lembaga PAUD B (02) berada tidak jauh dengan lokasi Lembaga pertama, Lembaga PAUD (02) menyatu dengan Posyandu, dan Poslansia, karena Lembaga tersebut belum memiliki gedung sendiri. Lembaga berada di lingkungan rumah penduduk. Ruangan samping rumah, ruangan atas rumah dan halaman depan rumah warga. Awalnya berdiri karena adanya posyandu di setiap RW, gedung menyatu dengan posyandu, dan poslansia, di depan jalan tidak begitu lebar tetapi cukup jika dilewati 1 mobil dan terdapat selokan yang mengalir didepannya. Berdirinya Lembaga tersebut atas dasar Pos PAUD yang harus dimiliki dari setiap RW Kelurahan. Kelurahan mendirikan Posyandu, Pos PAUD, dan Poslansia di setiap RW (CWG1-02) (CD2-02).

Lembaga PAUD $\mathrm{C}$ berada sangat jauh di antara kedua Lembaga lainnya, lingkungannya sangat asri walaupun jika dilihat ke depan jalan raya sangat bising oleh bisnis area. Lembaga ini mempunyai halaman yang sangat luas dan alami, masih terdapat pohonpohon besar. Desain arsitektur bangunan gedung memang tidak seperti sekolah biasanya tetapi seperti rumah saja, karena pada awalnya didirikan oleh keluarga, jadi kondisi seperti rumahnya tidak hilang (CD303).

Lembaga PAUD C (03) berada di belakang rumah pemiliknya, dilihat seperti pavilliun rumah yang dijadikan kelas, tetapi ini seperti rumah kedua bagi anak-anak ketika mereka berada di sekolah (CD4-03). Jika dilihat dari depan jalan raya sekolah ini berada di lingkungan area bisnis seperti restoran, hotel, supermarket, cafe, dan pertokoan. Suasana lingkungannya tidak merasa berada di pertengahan kota area bisnis karena suasana didalamnya tetap merasa sunyi dan tenang, dibelakang rumah terdapat rumah-rumah penduduk (CWG1-03).

Lembaga tersebut mempunyai 3 (tiga) ruang kelas di setiap kelas terdapat toilet, pantry, area bermain, dan perpustakaan. Resepsionis yang akan membantu pengunjungnya ketika masuk ke Lembaga tersebut. Jalan masuknya tidak terlalu besar hanya bisa dilalui oleh 1 mobil. Terdapat pohon-pohon besar dan rumputrumput di area depan kelas. Sejarah Lembaga PAUD (03) berdiri awalnya bu Yaya (pemilik dan pendiri sekolah) memiliki 2 balita, bu Yaya menginginkan anaknya ada teman bermain di rumah karena dulu Kemang masih sepi kemudian dibukalah playgroup di garasi rumah tepatnya. Tahun 1998 TK C mulai berkembang mempunyai 8 kelas playgroup. Tahun 2000 anak bu Yaya pulang dari Amerika dan menantang untuk membuat TK dan akhirnya pada tahun 2002 berdirilah TK Kembang dan merancang untuk membuuat SD, tahun 2003 berdirilah SD Kembang dan pada tahun 2009 dapat meluluskan lulusan pertama SD Kembang. Lembaga yang didirikan oleh keluarga, nilai utamanya anak-anak senang dan nilai-nilai kebahagiaan bermain (CWG1-03).

c. Gambaran Umum Subjek Penelitian

Nama dan beberapa identitas sengaja di tulis dengan inisial demi menjaga kenyamanan dan kerahasiaan subjek, untuk mengetahui lebih jelas 
tentang data informan tersebut, dapat dilihat pada tabel berikut:

Tabel 6. Data Informan I

\begin{tabular}{|c|c|c|}
\hline Nama & B.D & A.R \\
\hline Jabatan & $\begin{array}{c}\text { Ketua } \\
\text { Yayasan }\end{array}$ & $\begin{array}{c}\text { Kepala } \\
\text { Sekolah } \\
\text { dan Guru }\end{array}$ \\
\hline Usia & 44 Tahun & 31 Tahun \\
\hline $\begin{array}{c}\text { Pendidikan } \\
\text { Terakhir }\end{array}$ & S1 & S1 \\
\hline $\begin{array}{c}\text { Pengalaman } \\
\text { Mengajar }\end{array}$ & 20 Tahun & 9 Tahun \\
\hline
\end{tabular}

Guru ke-1 ialah Ketua Yayasan yang mendirikan yayasan, pemilik sekolah bertanggungjawab atas seluruh kegiatan yang dilaksanakan oleh sekolah. Ketua yayasan ikut terlibat langsung dalam menangani kegiatan sekolah. Terlihat setiap hari memantau kegiatan belajar mengajar di sekolah (CWG1-01).

Guru ke-2 ialah Kepala Sekolah yang merangkap sebagai guru dan tenaga administrasi. Tugas Kepala Sekolah adalah sebagai guru, setiap hari Kepala Sekolah mengajar anakanak karena kurangnya guru yang mengajar disekolah tersebut (CWG201).

Tabel 7. Data Informan II

\begin{tabular}{|c|c|c|}
\hline Nama & M.R & R.M \\
\hline Jabatan & KS & Guru \\
\hline Usia & 37 Tahun & 40 Tahun \\
\hline $\begin{array}{c}\text { Pendidikan } \\
\text { Terakhir }\end{array}$ & S1 & S1 \\
\hline $\begin{array}{c}\text { Pengalaman } \\
\text { Mengajar }\end{array}$ & 8 Tahun & 8 Tahun \\
\hline
\end{tabular}

Guru ke-1 ialah Kepala Sekolah yang bertanggungjawab mengurusi sekolah yang berada di naungan RW setiap kelurahan. Awalnya Ibu M.R adalah kader PKK dan diberi tanggungjawab untuk mengurusi Pos Paud (CWG1-02).

Guru ke-2 ialah guru yang mengajar di TK Flamboyan awalnya guru ini juga merupakan ibu-ibu kader PKK, tetapi diberi tugas untuk mengajar di Pos Paud karena setiap kader dibagi-bagi tugasnya ada yang mengurusi Posyandu, Pos Paud, dan Poslansia (CWG2-02).

Tabel 8. Data Informan III

\begin{tabular}{|c|c|c|}
\hline Nama & L. P & PRB \\
\hline Jabatan & $\begin{array}{c}\text { KS TK } \\
\text { Kembang }\end{array}$ & $\begin{array}{c}\text { Guru TK } \\
\text { Kembang }\end{array}$ \\
\hline Usia & 35 Tahun & 50 Tahun \\
\hline $\begin{array}{c}\text { Pendidikan } \\
\text { Terakhir }\end{array}$ & S1 & S1 \\
\hline $\begin{array}{c}\text { Pengalaman } \\
\text { Mengajar }\end{array}$ & 12 Tahun & 25 Tahun \\
\hline
\end{tabular}

Guru ke-1 ialah Kepala Sekolah yang di percayai oleh pemilik sekolah untuk mengurusi sekolah Kembang, karena pemilik sekolah sudah tidak ada karena meninggal dunia dan anaknya tidak bisa menggantikan akhirnya terpilihlah menjadi kepala sekolah Kembang. Dulu menjadi guru SD Kembang kelas 1 ketika awal masuk bergabung di Kembang (CWG1-03).

Guru ke-2 ialah guru TK kelompok B, pada awalnya mengajar Playgroup semenjak 2002 mengajar di TK Kembang sampai sekarang (CWG2-03).

\section{Temuan Khusus}

a. Kesiapsiagaan Lembaga PAUD

Sekolah perlu melakukan proses perencanaan, pengadaan dan perawatan fasilitas sekolah untuk mempertimbangkan kerentanan dan kerawanan terhadap bencana. Sekolah diharapkan akan menjadi wahana bagi masyarakat bagaimana merancang, melaksanakan, dan mengevakuasi ketika terjadi bencana. Adapun indikator sekolah aman yang termuat dalam Peraturan BNPB No. 4 Tahun 2012 tentang Pedoman Penerapan Sekolah Aman dari Bencana mengacu 
pada 2 aspek (struktural dan nonstruktural).

Hasil wawancara menunjukkan bahwa ketiga Lembaga PAUD mempunyai rencana kesiapsiagaan yang berbeda-berbeda sesuai dengan kondisi dan lingkungan masingmasing sekolah. Pada TK A, sebelum banjir terjadi guru sudah merapihkan barang-barang dan membungkusnya dengan plastik, dokumen-dokumen penting diamankan, dan barang-barang lainnya dibirakan dengan resiko rusak atau hanyut terbawa air. Guru melakukan hal tersebut dengan menggunakan daftar cek keselamatan untuk memastikan semua keadaan sudah aman dalam kondisi darurat menghadapi banjir yang akan datang (CWG1-01; CWG2-01).

Masyarakat lingkungan sekitar TK A pun bersiap siaga. Pada musim penghujan sekitar lingkungan TK A mendapat surat dari Kelurahan yang di berikan oleh setiap RT untuk membersihkan sampah di got-got sekitar lingkungannya pada setiap bulan musim penghujan agar jika banjir datang air dapat mengalir tidak tertahan oleh sampah yang ada di dalam got (CWMSY-01).

Guru pun mengajarkan kepada anak tentang siap siaga banjir melalui simulasi, membiasakan anak untuk menjaga kebersihan dan kesehatan pada saat banjir, mengajarkan tentang bahaya banjir, kondisi aman dan tidak aman melalui kegiatan diskusi sesuai dengan tema kegiatan di sekolah (CWG1-01; CWG2-01).

Pada TK B, ketika sudah masuk musim penghujan mereka membuat perencanaan untuk membersihkan dan merapihkan kelas seperti mengecat kelas dan lainnya, merapihkan barangbarang yang di amankan di lantai 2 (dua) jika terjadi banjir. Sama halnya dengan TK A guru TK B menggunakan daftar cek keselamatan untuk memastikan semua keadaan sudah aman dalam kondisi darurat menghadapi banjir yang akan datang (CWG1-02; CWG2-02). Terlihat pula kesiapsiagaan yang sama masyarakat
TK B dengan masyarakat TK A agar siapsiaga menghadapi banjir (CWMSY-02).

Guru TK B memberikan pengetahuan dan keterampilan sesuai tema seperti yang dilakukan guru TK A. Guru melakukan diskusi, simulasi tentang banjir dan bahayanya, menjagakebersihan dan kesehatan (CWG1-02; CWG2-02).

Guru TK C melakukan persiapan berdasarkan situasi kondisi lingkungan sekitar ketika musim penghujan. Ketika banjir mengelilingi lingkungan sekitar sekolah sudah menyebarluaskan informasi perihal kebijakan dispensasi masuk sekolah yang di berlakukan pada hari saat terjadi banjir. Daftar cek keselamatan juga digunakan oleh TK $\mathrm{C}$ untuk memastikan semua keadaan sudah aman dalam kondisi darurat menghadapi banjir yang akan datang (CWG1-03; CWG2-03).

Guru TK $C$ juga melakukan simulasi banjir, menjaga kebersihan dan kesehatan pada saat banjir, mengajarkan tentang bahaya banjir, kondisi aman dan tidak aman saat banjir, melalui kegiatan bermain peran, misalnya saat kegiatan olahraga. Anak-anak ada yang berperan sebagai korban banjir, timSAR, para relawan, dll. Sesuai dengan tema kegiatan di sekolah, anak-anak mengetahui apa yang harus di lakukan ketika banjir, menjaga kesehatan dan kebersihan pada saat banjir, mengetahui kondisi aman dan tidak aman pada saat keadaan darurat (CWG1-03; CWG2-03). Orangtua wali murid TK $\mathrm{C}$ berusaha untuk tetap sampai ke sekolah melalui akses yang diinformasikan pihak sekolah (CWOT1-03; CWOT2-03).

b. Kategorisasi Kesiapsiagaan

Berikut adalah kategorisasi kesiapsiagaan Lembaga PAUD dalam menghadapi banjir yang dikelompokkan dalam 3 (tiga) bagian: (1) Aspek struktural; (2) Aspek NonStruktural; (3) Ideal Lembaga PAUD dari segi pengetahuan yang harus 
dimiliki oleh guru dan murid. Kategorisasi siap siaga yang dimaksud jika sekolah memenuhi seluruh indikator dari ketiga aspek tersebut. Lembaga yang dikategorikan siap siaga adalah Lembaga PAUD yang memenuhi seluruh aspek indikator. Lembaga yang dikategorikan kurang siap siaga adalah Lembaga PAUD yang hanya dapat memenuhi kurang dari (<) 26 indikator dari seluruh kategorisasi kesiapsiagaan, dan jika Lembaga PAUD hanya dapat memenuhi kurang dari $(<) \quad 15$ indikator dari seluruh aspek kategorisasi kesiapsiagaan dapat dikategorisasikan tidak siap siaga.

Dari hasil data wawancara tersebut dapat diketahui dari 16 indikator bahwa Lembaga PAUD (01) telah memenuhi 8 indikator pada aspek nonstruktural, Lembaga PAUD (02) telah memenuhi 9 indikator pada aspek nonstruktural, dan Lembaga PAUD (03) telah memenuhi 9 indikator pada aspek non-struktural, masing-masing terdiri dari 4 aspek yaitu: Kapasitas; (2) Perencanaan; (3) Kebijakan; dan (4) Mobilisasi Sumber Daya.

Dari hasil data observasi tersebut dapat diketahui dari 17 indikator bahwa Lembaga PAUD A (01) telah memenuhi 13 indikator pada aspek struktural, Lembaga PAUD B (02) telah memenuhi 13 indikator pada aspek non-struktural, dan Lembaga PAUD C (03) telah memenuhi 14 indikator pada aspek struktural, masing-masing terdiri dari 3 aspek yaitu: (1) Struktur Bangunan; (2) Arsitektural; dan (3) Tata Ruang.

Dari hasil data wawancara tersebut dapat diketahui bahwa Lembaga PAUD A telah memenuhi 2 indikator berdasarkan aspek ideal Lembaga PAUD dari segi pengetahuan, Lembaga PAUD B telah memenuhi 2 indikator pada aspek ideal Lembaga PAUD dari segi pengetahuan, dan Lembaga PAUD $\mathrm{C}$ telah memenuhi 2 indikator pada aspek ideal Lembaga PAUD dari segi pengetahuan, masingmasing terdiri dari 4 indikator yaitu:
(1) Mengikuti pelatihan atau pembekalan tentang penanggulangan bencana dan resiko bencana; (2) Melakukan kajian risiko di sekitar lokasi Lembaga PAUD; (3) Merencanakan integrasi kurikulum ke dalam Rencana Belajar; (4) Memadukan pendidikan kesiapsiagaan bencana ke dalam kebijakan sekolah.

\section{B. Pembahasan}

1. Kesiapsiagaan Lembaga PAUD

Kesiapsiagaan Lembaga PAUD pertama adalah TK A yang berada di daerah rentan bencana banjir. Lembaga yang terkena bencana banjir namun tetap melakukan proses pembelajaran pada saat keadaan darurat karena meyakini pentingnya diadakan proses pembelajaran di saat keadaan darurat, anak-anak perlu mendapat pembelajaran walaupun dalam keadaan darurat.

Terlihat kesiapsiagaan yang dilakukan TK A dalam melakukan kesiapsiagaan menghadapi banjir, segala bentuk upaya yang dilakukan atas dasar pengalaman yang pernah di alami dari tahun ke tahun menghadapi bencana banjir. Persiapan sebelum banjir berupa merapikan barangbarang di bungkus dengan plastik dan di simpan di lantai 2. Dokumen-dokumen penting diamankan dan anak mendapatkan pembelajaran menghadapi banjir, menjaga kesehatan dan kebersihan, mengenal kondisi aman dan tidak aman di pelajari dengan kegiatan diskusi di kelas sesuai dengan tema kegiatan.

Kegiatan proses pembelajaran yang dilakukan dalam keadaan darurat memang tidak bisa optimal tetapi guru memaksimalkan seluruh kemampuannya untuk memberikan pembelajaran dalam kondisi darurat. Kegiatan pemulihan dilakukan secara terus menerus, mempertimbangkan pentingnya keperluan yang harus didahulukan membuat guru harus mengatur semua kondisi yang ada di sekolah dengan keterbatasan donasi biaya yang diberikan oleh setiap donatur perorangan. Pemilihan barang-barang peralatan dari bahan pelastik memudahkan guru untuk menyelamatkannya. Tanpa ada perencanaan yang tertulis membuat guru 
harus mempersiapkan segala sesuatunya dengan pengalaman saja.

Hal tersebut sesuai dengan peraturan BNPB No. 4 Tahun 2012 berdasarkan indikator sekolah aman pada aspek nonstruktural yang terdiri dari kapasitas, perencanaan, kebijakan, mobilisasi sumber daya, dan menurut Andina (2011) Lembaga PAUD harus melakukan serangkaian kegiatan sebagai berikut: (1) Merencanakan integrasi kurikulum ke dalam Rencana Belajar Tahunan, Bulanan, Mingguan dan Harian serta pemantauan hasil belajar; (2) Memadukan pendidikan kesiagaan bencana ke dalam kebijakan sekolah.

Kesiapsiagaan Lembaga PAUD yang kedua adalah TK B yang berada di daerah rentan bencana. TK B menyewa gedung karena belum memiliki gedung khusus untuk melakukan proses pembelajaran setiap harinya. TK B hampir setiap 5 tahun sekali mengalami banjir dan tentu mengakibatkan banyak kerugian. Gedung sekolah TK B berdampingan dengan Posyandu, dan Poslansia karena Lembaga ini didirikan atas dasar kepemilikan Pos PAUD pada setiap RW di kelurahan.

Anak-anak mendapatkan pembelajaran tentang menghadapi banjir, menjaga kesehatan dan kebersihan, mengenal kondisi aman dan tidak aman di pelajari dengan kegiatan diskusi di kelas sesuai dengan tema kegiatan. Setiap terkena banjir TK B tidak pernah melakukan proses pembelajaran karena mempertimbangkan segala kondisi dan situasi pada saat keadaan darurat, tidak melakukan proses pembelajaran merupakan resiko bagi Lembaga PAUD yang berada di daerah rentan banjir. Pemulihan kondisi setelah banjir berkoordinasi dengan orangtua dan lembaga HIMPAUDI dalam membersihkan dan merapihkan barangbarang yang disimpan di lantai 2 .

Hal tersebut sesuai dengan peraturan BNPB No. 4 Tahun 2012 berdasarkan indikator sekolah aman pada aspek nonstruktural yang terdiri dari kapasitas, perencanaan, kebijakan, mobilisasi sumber daya, dan menurut Andina (2011) Lembaga PAUD harus melakukan serangkaian kegiatan sebagai berikut: (1)
Merencanakan integrasi kurikulum ke dalam Rencana Belajar Tahunan, Bulanan, Mingguan dan Harian serta pemantauan hasil belajar; (2) Memadukan pendidikan kesiagaan bencana ke dalam kebijakan sekolah.

Kesiapsiagaan Lembaga PAUD ketiga adalah TK $\mathrm{C}$ yang berada dilokasi rentan banjir pada akses jalan, TK $\mathrm{C}$ tidak pernah mengalami banjir tetapi hanya akses nya saja yang menjadi hambatan terkena banjir. TK $\mathrm{C}$ berada di tengah-tengah pada akses jalan yang terkena banjir, di kelilingi akses jalan yang terkena banjir mengakibatkan sekolah harus mempunyai kesiapsiagaan dalam menghadapinya.

Anak-anak mendapatkan pembelajaran menghadapi banjir, menjaga kesehatan dan kebersihan, mengenal kondisi aman dan tidak aman melalui kegiatan bermain peran ketika anak-anak sedang olahraga di lapangan SD XYZ yang berdekatan dengan lokasi TK C. Anak-anak mengenali apa yang harus di lakukan ketika banjir dan sudah mendengar peringatan, anak-anak mengetahui bagaimana kondisi aman dan tidak aman, menjaga kesehatan dan kebersihan ketika kondisi darurat dari pembelajaran tersebut yang di sesuaikan dengan tema kegiatan. Lembaga tersebut berupaya untuk tetap melakukan proses pembelajaran dalam kondisi darurat, upaya yang dilakukan memberikan dispensasi masuk akibat banjir karena sulitnya anak dan orangtua melewati jalanan yang terkena akses banjir. Pada saat banjir pihak Lembaga mencari info yang akurat tentang kebenarannya dan segera menginformasikan kepada orangtua. Pemulihan kondisi normal akan berjalan seperti biasanya.

Hal tersebut sesuai dengan peraturan BNPB No. 4 Tahun 2012 berdasarkan indikator sekolah aman pada aspek nonstruktural yang terdiri dari kapasitas, perencanaan, kebijakan, mobilisasi sumber daya, dan menurut Andina (2011) Lembaga PAUD harus melakukan serangkaian kegiatan sebagai berikut: (1) Merencanakan integrasi kurikulum ke dalam Rencana Belajar Tahunan, Bulanan, Mingguan dan Harian serta pemantauan hasil belajar; (2) Memadukan pendidikan 
kesiagaan bencana ke dalam kebijakan sekolah.

2. Kategorisasi Kesiapsiagaan

Berdasarkan hasil wawancara dan observasi yang dilakukan oleh penulis dapat diketahui bahwa Lembaga PAUD A memenuhi 23 indikator dari ketiga aspek kategorisasi kesiapsiagaan yang terdiri dari 8 indikator dari aspek non-struktural, 13 indikator dari aspek struktural, dan 2 aspek dari aspek idealnya Lembaga PAUD dari segi pengetahuan. Terlihat bahwa dari aspek non struktural Lembaga PAUD A: (1) Tidak memiliki peta-peta hasil penilaian kondisi sekolah aman; (2) Tidak memiliki rencana induk sekolah aman; (3) Tidak memiliki DED rehabilitasi bangunan sekolah yang tahan gempa; (4) Tidak memiliki RAB rehabilitasi sekolah aman; (5) Tidak memiliki rencana aksi tahunan; (6) Tidak memiliki Komite Bencana dan Keselamatan Sekolah; (7) Tidak Memiliki sarana dan prasarana untuk tanggap darurat seperti tendu dan P3K; (8) Tidak memiliki poster jalur evakuasi yang dipasang di tempat strategis. Terlihat bahwa dari aspek struktural Lembaga PAUD A: (1) Tidak Terlihat Dimensi besi sesuai dengan standar Permen; (2) Tidak terlihat ikatan antar komponen sesuai dengan ketentuan teknis PU; (3) Tidak terlihat alat pemadam kebakaran; (4) Tidak terdapat tiang bendera, lemari, dan papan nama. Terlihat dari aspek idealnya Lembaga PAUD dari segi pengetahuan Lembaga PAUD A: (1) Tidak melakukan pelatihan/ pembekalan tentang penanggulangan bencana; (2) Tidak melakukan kajian resiko di sekitar lokasi Lembaga PAUD. Hasil penelitian menunjukan bahwa Lembaga PAUD A memenuhi 23 indikator, maka dapat dikategorisasikan untuk Lembaga PAUD A merupakan Lembaga kurang siap siaga dalam menghadapi bencana banjir.

Lembaga PAUD B memenuhi 24 indikator dari ketiga aspek kategorisasi kesiapsiagaan yang terdiri dari 9 indikator dari aspek non-struktural, 13 indikator dari aspek struktural, dan 2 aspek dari aspek idealnya Lembaga PAUD dari segi pengetahuan. Terlihat bahwa dari aspek non struktural Lembaga PAUD B: (1)
Tidak memiliki peta-peta hasil penilaian kondisi sekolah aman; (2) Tidak memiliki rencana induk sekolah aman; (3) Tidak memiliki DED rehabilitasi bangunan sekolah yang tahan gempa; (4) Tidak memiliki RAB rehabilitasi sekolah aman; (5) Tidak memiliki rencana aksi tahunan; (6) Memiliki sarana dan prasarana untuk tanggap darurat seperti tendu dan P3K; (7) Tidak memiliki poster jalur evakuasi yang dipasang di tempat strategis. Terlihat bahwa dari aspek struktural Lembaga PAUD B: (1) Tidak terlihat ikatan antar komponen sesuai dengan ketentuan teknis PU; (2) Tidak terlihat pintu 2 daun dan terbuka lebar (3) Tidak terlihat alat pemadam kebakaran; (4) Tidak terdapat tiang bendera, lemari, dan papan nama. Terlihat dari aspek idealnya Lembaga PAUD dari segi pengetahuan Lembaga PAUD B : (1) Tidak melakukan pelatihan/ pembekalan tentang penanggulangan bencana; (2) Tidak melakukan kajian resiko di sekitar lokasi Lembaga PAUD. Hasil penelitian menunjukan bahwa Lembaga PAUD B memenuhi 24 indikator, maka dapat dikategorisasikan untuk Lembaga PAUD B merupakan Lembaga kurang siap siaga dalam menghadapi bencana banjir.

Lembaga PAUD C memenuhi 25 indikator dari ketiga aspek kategorisasi kesiapsiagaan yang terdiri dari 9 indikator dari aspek non-struktural, 14 indikator dari aspek struktural, dan 2 aspek dari aspek idealnya Lembaga PAUD dari segi pengetahuan. Terlihat bahwa dari aspek non struktural Lembaga PAUD C: (1) Tidak memiliki peta-peta hasil penilaian kondisi sekolah aman; (2) Tidak memiliki rencana induk sekolah aman; (3) Tidak memiliki DED rehabilitasi bangunan sekolah yang tahan gempa; (4) Tidak memiliki RAB rehabilitasi sekolah aman; (5) Tidak memiliki rencana aksi tahunan; (6) Tidak memiliki Komite Bencana dan Keselamatan Sekolah; (7) Tidak memiliki poster jalur evakuasi yang dipasang di tempat strategis.. Terlihat bahwa dari aspek struktural Lembaga PAUD C: (1) Tidak terlihat ikatan antar komponen sesuai dengan ketentuan teknis PU; (2) Tidak terlihat pintu 2 daun dan terbuka lebar (3) Tidak terlihat alat pemadam 
kebakaran. Terlihat dari aspek idealnya Lembaga PAUD dari segi pengetahuan Lembaga PAUD C: (1) Tidak melakukan pelatihan/ pembekalan tentang penanggulangan bencana; (2) Tidak melakukan kajian resiko di sekitar lokasi Lembaga PAUD. Hasil penelitian menunjukan bahwa Lembaga PAUD C memenuhi 25 indikator, maka dapat dikategorisasikan untuk Lembaga PAUD $\mathrm{C}$ merupakan Lembaga kurang siap siaga dalam menghadapi bencana banjir.

\section{SIMPULAN DAN SARAN}

\section{A. Simpulan}

Berdasarkan penelitian yang dilakukan, maka dapat ditarik kesimpulan bahwa:

1. Kesiapsiagaan Lembaga PAUD

Berdasarkan hasil penelitian keragaman kesiapsiagaan di Lembaga Pendidikan Anak Usia Dini dalam mengahadapi bencana banjir untuk mengurangi risiko bencana dan dalam rangka kesiapsiagaan mengantisipasi bencana banjir terlihat adanya keberagaman yang dilakukan sesuai dengan kondisi masing-masing lingkungan sekolah. Lembaga PAUD A terlihat lebih memprioritaskan kesiapsiagaan untuk mengamankan peralatan sekolah dan mempersiapkan peralatan sekolah pada saat kondisi darurat, sedangkan Lembaga PAUD B terlihat lebih memprioritaskan kesiapsiagaan untuk mengamankan peralatan sekolah, dan Lembaga PAUD C terlihat lebih memprioritaskan keselamatan anak dan orangtua dalam kesiapsiagaan menghadapi banjir. Kesiapsiagaan dilakukan dalam rangka upaya mengelola risiko bencana, sehingga jika telah siaga dampak dari bencana dapat diminimalisir.

2. Kategorisasi kesiapsiagaan

Berdasarkan hasil penelitian dari ketiga Lembaga Pendidikan Anak Usia Dini dalam menghadapi bencana banjir dapat diketahui bahwa ketiga Lembaga PAUD termasuk dalam kategorisasi kurang siap siaga dalam menghadapi bencana banjir karena setiap Lembaga PAUD hanya dapat memenuhi kurang dari (<) 26 indikator dari setiap aspek kategorisasi kesiapsiagaan yang terdiri dari: (1) Aspek Struktural; (2) Aspek NonStruktural; dan (3) Aspek pengetahuan yang harus dimiliki oleh setiap guru dan siswa.

\section{B. Saran}

Berdasarkan kesimpulan yang didapat, maka penulis mencoba untuk memberikan saran, yaitu:

1. Lembaga PAUD perlu bekerjasama dengan pihak PEMDA atau Lembaga Pemerintahan untuk mempersiapkan bangunan sekolah aman yang sesuai dengan standar pembangunan sekolah aman yang termuat dalam peraturan BNPB No. 4 Tahun 2012 terdiri dari aspek struktural dan non struktural.

2. Lembaga PAUD hendaknya melakukan pelatihan atau seminar untuk guru agar memiliki pengetahuan, sikap, dan keterampilan menghadapi bencana banjir di sekolah.

3. Lembaga PAUD hendaknya melakukan pelatihan atau seminar untuk bagian administrasi agar memiliki pengetahuan, sikap, dan keterampilan menghadapi bencana banjir di sekolah.

\section{TINJAUAN PUSTAKA}

Ariantoni, dkk. (2009). Pengintegrasian pengurangan resiko bencana dalam sistem pendidikan. Jakarta: Kemendiknas.

Astuti, M., dkk. (2013). Kebijakan kesejahteraan dan perlindungan anak. Jakarta : Kemensos RI.

Maryana, R., dkk. (2010). Pengelolaan lingkungan belajar. Jakarta: Kencana.

Moleong, L.J. (2002). Metodologi penelitian kualitatif. Bandung: Remaja Rosdakarya.

Moleong, L.J. (2005). Metodologi penelitian kualitatif. Bandung: Remaja Rosdakarya.

Mukhtar. (2013). Metode praktis penelitian deskriptif kualitatif . Jakarta: GP Press group. 
Jurnal AUDHI, Vol. 1, No. 1, Juli 2018

Sugiyono. (2005). Memahami penelitian kualitatif. Bandung: Alfabeta

UNESCO. (2007). Partisipasi masyarakat dalam penanggulangan banjir. Jakarta: Bappeda. 